\title{
SYNTHESIS OF A-RING-SUBSTITUTED 5,6,8,12B-TETRAHYDROISOINDOLO[1,2-A]ISOQUINOLIN-8-ONES
}

\author{
VICENTE CASTRO-CASTILLO ${ }^{1,2}$ MARCO REBOLLEDO-FUENTES, ${ }^{1}$ BRUCE K. CASSELS, ${ }^{1,3^{*}}$ \\ ${ }^{1}$ Department of Chemistry, Faculty of Sciences, University of Chile, Santiago, Chile. \\ ${ }^{2}$ Department of Chemistry, Faculty of Basic Sciences, Metropolitan Educational Sciences University, Santiago, Chile. \\ ${ }^{3}$ Institute for Cell Dynamics and Biotechnology, University of Chile, Santiago, Chile. \\ (Received: March 23, 2009 - Accepted: July 20, 2009)
}

\begin{abstract}
The synthesis of 4,5,8,12b-tetrahydroisoindolo[1,2-a]isoquinolin-8-ones is reviewed The unsubstituted parent compound, a series of fourteen A-ringsubstituted derivatives, most of them new, and some of their doubly benzylic, 12b-hydroxylated oxidation products were synthesized. Unusual features of their reactivity are briefly discussed.
\end{abstract}

\section{INTRODUCTION}

The isoindolo[1,2- $a$ ] isoquinoline structure (1), with its rigid tetracyclic scaffold and its many possible sites of substitution, is isomeric with the relatively well studied indeno[1,2-c]isoquinolines. ${ }^{1}$ Like the latter, $\mathbf{1}$ can be predicted to be a "privileged" structure in the sense that it is "a substructural feature which confers desirable (often drug-like) properties on compounds containing that feature". ${ }^{2}$ Considering its long history and relative ease of synthesis, one would expect the isoindolo[1,2- $a$ ] isoquinoline framework to have been extensively exploited for pharmacological studies, but this is not the case (Figure 1).

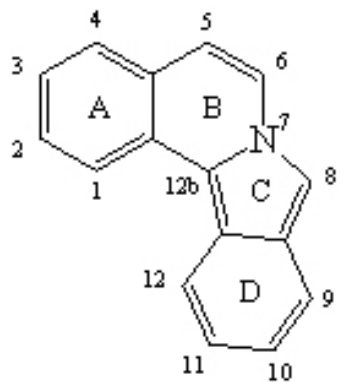

$\mathbf{A}$

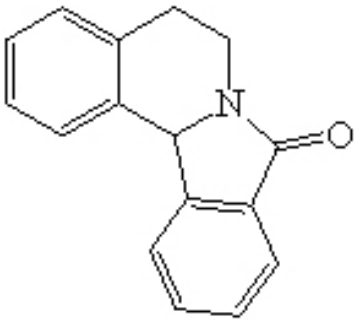

1

\section{Figure 1}

Synthesis of the fully aromatic parent compound (A) does not seem to have been attempted. The first substance incorporating this skeleton, $( \pm)-5,6,8,12 \mathrm{~b}-$ tetrahydroisoindolo[1,2- $a$ ]isoquinolin-8-one (1), was synthesized four decades ago by cyclization of the condensation product of 2-phenylethylamine and phthalaldehydic acid (2-carboxybenzaldehyde) - presumably 3-(2phenylethylamino)phthalide - catalyzed by concentrated sulfuric acid at room temperature, and its 2,3-dimethoxy-12b-phenyl derivative was prepared by an analogous route. ${ }^{3}$ Shortly thereafter, polyphosphoric acid at $100{ }^{\circ} \mathrm{C}$ was also found to effect this cyclization to give $\mathbf{1}$ (Scheme 1). ${ }^{4}$<smiles>O=C1OC(NCCc2ccccc2)c2ccccc21</smiles>
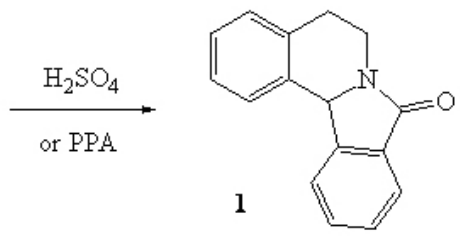

Scheme 1

Substituted derivatives of phthalaldehydic acid are not as readily available as substituted phthalic anhydrides and their $N$-substituted imides, curtailing the preparation of ring D-substituted isoindolo[1,2-a]isoquinoline derivatives following this approach. An alternative synthesis involving the sodium borohydride reduction (at moderately high temperature) of $N$-[2-phenylethyl]- (ring-substituted) phthalimide to afford the corresponding 3-hydroxyisoindolin1 -one and cyclization of the latter using concentrated hydrochloric acid led to the synthesis of a couple of ring D-substituted analogues, i.e. $( \pm)-10,11$ dimethoxy-5,6,8,12b-tetrahydroisoindolo[1,2- $a$ ] isoquinolin- 8 -one and its $12 \mathrm{~b}$ hydroxy derivative, the latter formed in excellent yield by oxidation of the former with air in alkaline solution (Scheme 2$)^{5}$

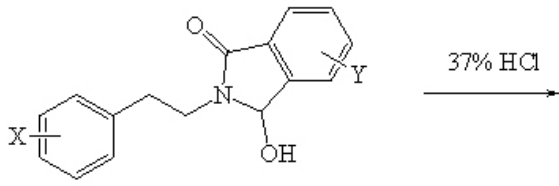<smiles>[X][Y]1ccc2c(c1)CCN1C(=O)c3ccccc3C21</smiles>

Scheme 2

This procedure, starting from $N$-phenylethylphthalimide and effecting the cyclization with concentrated hydrochloric acid (Scheme 2), proved to be a most convenient route for the preparation of $\mathbf{1}{ }^{6}$

$( \pm)$-12b-Butyl-2,3-dimethoxy-5,6,8,12b-tetrahydroisoindolo[1,2-a] isoquinolin-8-one was prepared by treating $N$-[2-(3,4-dimethoxyphenyl) ethyl]phthalimide with butyllithium to give 3-butyl-3-hydroxyisoindolin1 -one which was then cyclized using trifluoroacetic acid. ${ }^{7}$ These closely related syntheses are presumed to proceed via an intermediate $N$-acyliminium ion (Figure 2), first suggested by Moniot et al. in the course of a study on transformation products of the abundant alkaloid berberine. ${ }^{8}$

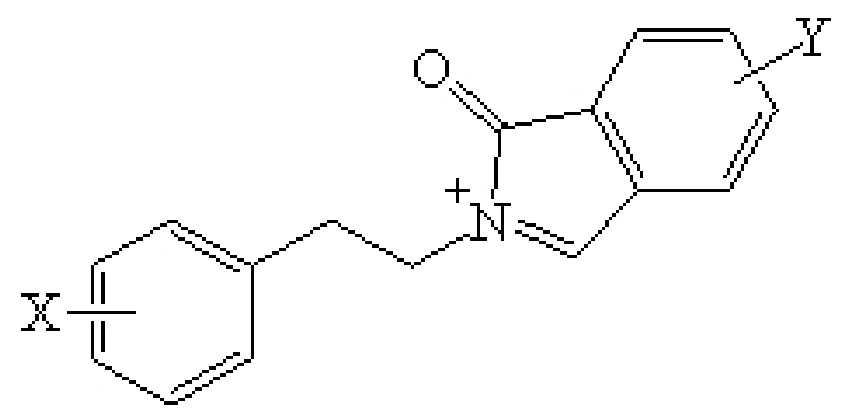

Figure 2

A variation of the former approach is that of Heaney and Shuhaibar. ${ }^{9}$ The latter authors converted $\mathrm{N}$-substituted 3-hydroxyisoindolin-1-ones, via the chloro compounds, into the 3-methoxy analogues, which were used as an alternative source of the $N$-acyliminium ion using trimethylsilyl triflate or various transition metal Lewis acids..$^{10}$ Another route involved the condensation of 2-phenylethylamine or its 4-methoxy or 3,4-dimethoxy analogues with phthalaldehydic acid and benzotriazole, which upon treatment with titanium 
tetrachloride generated the $N$-acyliminium intermediates and the corresponding isoindolo[1,2- $a]$ isoquinoline-8-ones $(\mathbf{1}, \mathbf{4}$, and $\mathbf{6}$, Figure 3$)$. The same strategy was used to synthesize a couple of chiral 5- and/or 6-substituted analogues of $1^{11}$<smiles>COc1ccc2c(c1)C1c3ccccc3C(=O)N1CC2</smiles><smiles>COc1cc2c(cc1OC)C1c3ccccc3C(=O)N1CC2</smiles>

6

Figure 3

While studying transformations of the alkaloid berberine, an isoindolo $[1,2-a]$ isoquinoline derivative was isolated and assigned structure $\mathbf{B}$, based in part on the substituent pattern of berberine and its close congeners. ${ }^{8} \mathrm{~A}$ few years later the same substance was found in an extract of Berberis darwinii Hook., native to south-central Chile and southwestern Argentina, and named nuevamine. ${ }^{12}$ Shortly thereafter the unambiguous syntheses of $( \pm)$-2,3-dimethoxy- (6), $( \pm)-2,3,9,10$-tetramethoxy-, and $( \pm)$-9,10-dimethoxy-2,3-methylenedioxy4,5,8,12b-tetrahydroisoindolo[1,2-a]isoquinolin-8-one (B) by trifluoroacetic acid-catalyzed cyclization of the appropriately substituted 3-hydroxyisoindolin1 -ones, and the documentation of a strong NOE between the protons at C-1 and $\mathbf{C}-12$ of $\mathbf{B}$, showed that the formula of nuevamine should be revised to $\mathbf{C}$ (11,12-dimethoxy-2,3-methylenedioxy-4,5,8,12b-tetrahydroisoindolo[1,2- $a]$ isoquinolin-8-one). Nuevamine (C) was then synthesized to confirm the revised structure (Figure 4). ${ }^{13}$
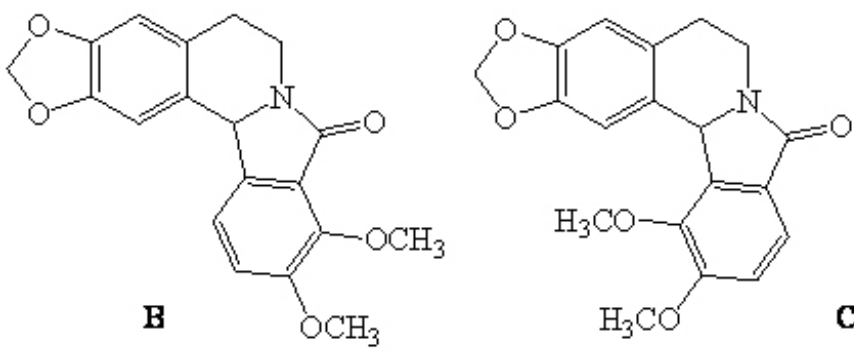

Figure 4

Further exploitation of the $N$-acyliminium approach (via the appropriately substituted 3-methoxyisoindolin-1-one and catalysis with boron trifluoride etherate) led to the 12b-hydroxymethyl derivative of $\mathbf{B}$, which underwent ring expansion to an isoindolobenzazepine precursor of the Berberis alkaloids lennoxamine and chilenine (Scheme 3). ${ }^{14}$

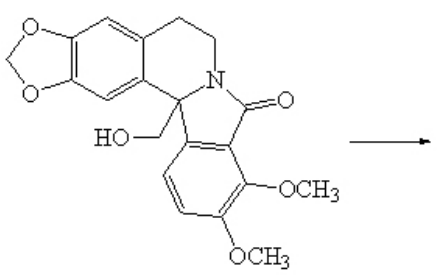<smiles>[R]C1=C2c3ccc(OC)c(OC)c3C(=O)N2CCc2cc3c(cc21)OCO3</smiles>

\section{Scheme 3}

Starting from enantiomerically pure (S)-phenylalaninol, a hydrooxazoloisoindolinone was prepared and cyclized with a variety of different Lewis acids $\left(\mathrm{SnCl}_{4}, \mathrm{TiCl}_{4}, \mathrm{BF}_{3} . \mathrm{OEt}, \mathrm{H}_{2} \mathrm{SO}_{4}, \mathrm{TMSOTf}\right)$ to give a mixture of diasteroisomers in excellent yield and, when trimethylsilyl triflate was used as the activator, a high degree of diastereoselectivity (Scheme 4): ${ }^{15}$

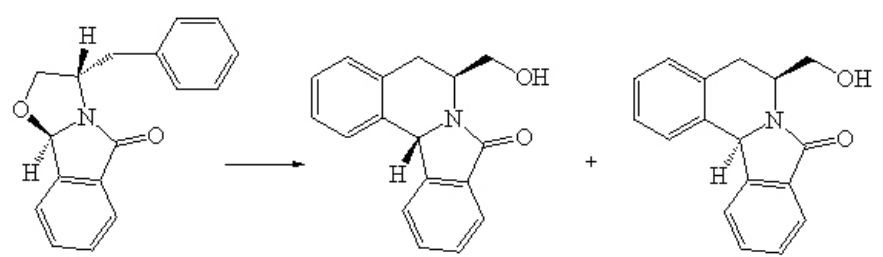

Scheme 4

In a completely different approach, intramolecular Heck cyclizations of 1-alkylidene-1,2,3,4-tetrahydroisoquinoline 2-iodobenzamides have been used, generating C-12b-alkylated products (Scheme 5). ${ }^{16,17}$<smiles>[R]C=C1c2ccccc2CCN1C(=O)c1ccccc1[X]</smiles>

\section{Scheme 5}

Palladium-catalyzed carbonylation of 6,7-dimethoxy-1-(2-iodophenyl)1,2,3,4-tetrahydroisoquinoline provided an alternative route to $\mathbf{6}$, and also to its 6-methoxycarbonyl derivative (Scheme 6). ${ }^{18}$<smiles>COc1cc2c(cc1OC)C(c1ccccc1I)NCC2</smiles><smiles>CC(C)OCCO</smiles><smiles>COc1cc2c(cc1OC)C1c3ccccc3C(=O)N1CC2</smiles>

\section{Scheme 6} ago. 19,2

All the former strategies were reviewed briefly four and five years

6A, which can be easily reduced to $\mathbf{6}$ (vide infra) was obtained by a Parham cyclization of $N$-[2-(4,5-dimethoxy-2-iodophenyl)ethyl]phthalimide (Scheme 7). ${ }^{7}$

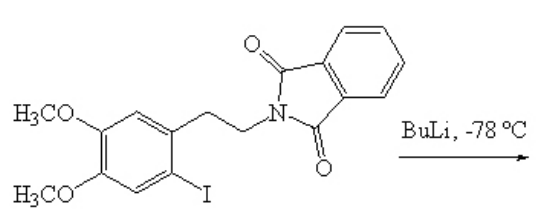<smiles>COc1cc2c(cc1OC)C1(O)c3ccccc3C(=O)N1CC2</smiles>

6A

\section{Scheme 7}

A tandem Parham sequence involving the successive reaction of 2-bromobenzyl)-[2-(2-fluorophenyl)ethyl]carbamic acid methyl esters with $t$-butyllithium and of the resulting fluorinated isoindolinones with potassium hexamethyldisilazane afforded a new synthesis of nuevamine (C) as well as 1 and its 11-benzyloxy-10-methoxy- and 10,11-methylenedioxy analogues (Scheme 8). ${ }^{19}$ 
<smiles>COC(=O)N(CCc1cc2c(cc1F)OCO2)Cc1c(Br)ccc(OC)c1OC</smiles><smiles>COc1ccc2c(c1OC)CN(CCc1cc3c(cc1F)OCO3)C2=O</smiles><smiles>COc1ccc2c(c1OC)C1c3cc4c(cc3CCN1C2=O)OCO4</smiles>

Scheme 8

Nuevamine (C) was synthesized again (and also 6) using two successive Parham procedures, the first to generate the appropriate dihydroisoquinolin1 -one, and the second to close the 5-membered ring. Reduction of the12bhydroxy compound was achieved with triethylsilane (Scheme 9). ${ }^{20}$<smiles>COc1ccc(C(=O)Cl)c(Br)c1OC</smiles><smiles>COC1=CC=C(C(=O)N2CCc3cc4c(cc3C2O)OCO4)C(Br)C1OC</smiles><smiles>COc1ccc2c(c1OC)C1(O)c3cc4c(cc3CCN1C2=O)OCO4</smiles><smiles>COc1ccc2c(c1OC)C1c3cc4c(cc3CCN1C2=O)OCO4</smiles>

Scheme 9

Two new synthetic routes of nuevamine have been reported very recently. ${ }^{21,22}$ The first involved a six-step synthesis of $\mathbf{C}$ with a key benzylic air-oxidation reaction of $N$-homopiperonyl-5,6-dimethoxyhomophtalimide (D) to $N$-homopiperonyl-5,6-dimethoxyisoquinoline-1,3,4-trione (E), followed by the regioselective alcoholysis of the trione with ring contraction and cyclizaton in TFA with decarboxylation to afford nuevamine (Scheme 10). ${ }^{21}$<smiles>CCOc1ccc(CCN2C(=O)c3ccc(OC)c(OC)c3C(=O)C2C(=O)O)cc1CCN1C(=O)Cc2c(ccc(OC)c2OC)C1=O</smiles>

Scheme 10

The latest synthetic route reported for $\mathbf{C}$ involved the reaction between 1-furyl-1,2,3,4-tetrahydroisoquinolines and unsaturated acid derivatives (acrylyl, methacrylyl, and crotonyl chloride, maleic and citraconic anhydride) followed in a one-pot procedure by an intramolecular Diels-Alder reaction of the furan moiety with the unsaturated acid residue (Scheme 11).22
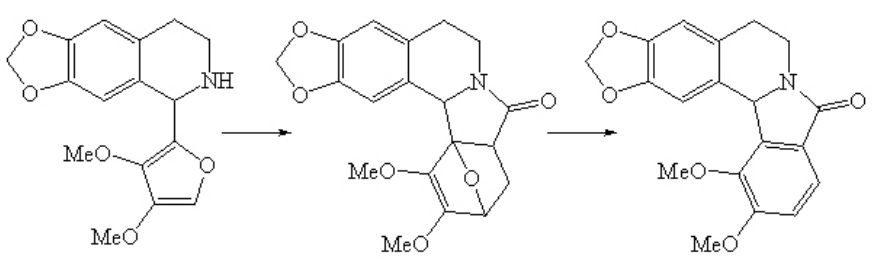

C

\section{Scheme 11}

It was shown in 2004 that $\mathbf{6 A}$ (see Scheme 7) can be reduced to $\mathbf{6}$ in almost quantitative yield with trifluoroacetic acid/sodium borohydride. ${ }^{23}$ Importantly, the same paper showed that treatment of $\mathbf{6 A}$ with a variety of $\pi$-nucleophilederived silanes or silyl ethers and either titanium tetrachloride or boron trifluoride etherate led in several cases to efficient nucleophilic substitution at $\mathrm{C}-12 \mathrm{~b}$.

The diastereomeric mixture of racemic 5-phenylthio-5,6,8,12btetrahydroisoindolo[1,2- $a$ isoquinolin-8-ones, which loses thiophenol at room temperature producing the dehydrogenated analogue of $1,( \pm)-8,12 \mathrm{~b}-$ dihydroisoindolo[1,2- $a$ ] isoquinolin-8-one, was only prepared quite recently (Scheme 12). ${ }^{24}$

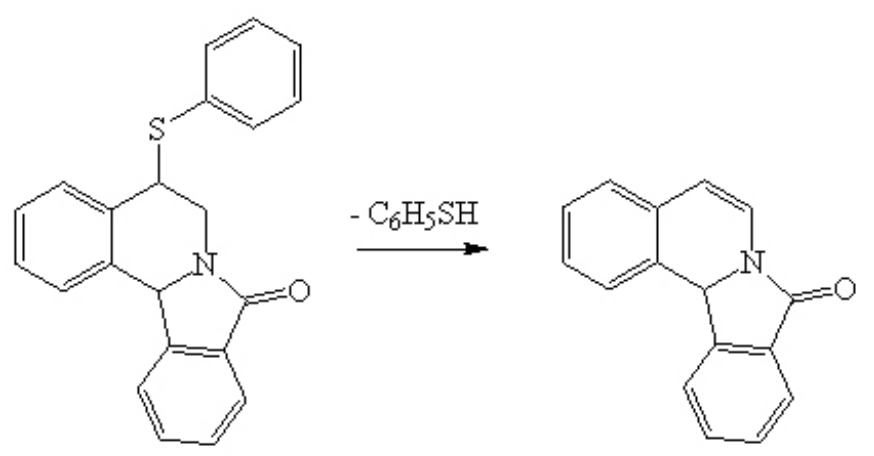

\section{Scheme 12}

The strategy to construct the arylthio compound involved a lengthy sequence ending with the high-yielding Pummerer cyclization of a sulfoxide intermediate with trifluoroacetic anhydride at room temperature (Scheme 13):

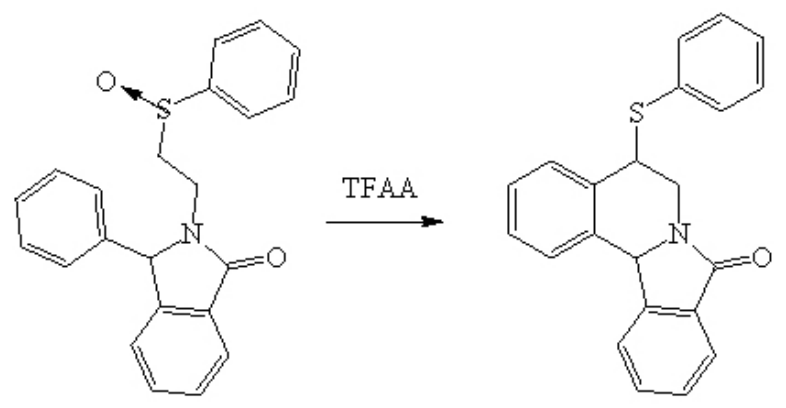

\section{Scheme 13}

The analogous reaction of an aldehyde intermediate was much less satisfactory (Scheme 14): $:^{24}$ 
<smiles>O=CCCN1C(=O)c2ccccc2C1c1ccccc1</smiles>

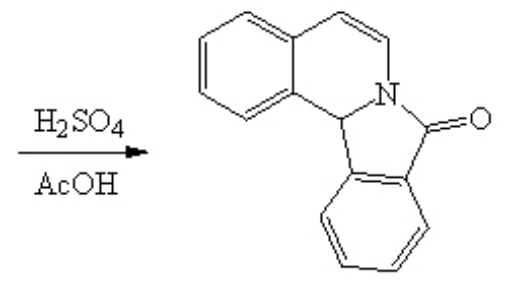

Scheme 14

Lithium aluminium hydride reduction of $\mathbf{1}$ is claimed to have afforded the corresponding amine, $( \pm)-5,6,8,12 \mathrm{~b}$-tetrahydroisoindolo[1,2-a] isoquinoline, in rather surprisingly low yield, together with the likely air-oxidation product $\mathbf{1 A}$, ( \pm )-12b-hydroxy-5,6,8,12b-tetrahydroisoindolo[1,2-a] isoquinolin-8-one. ${ }^{4}$ The latter unexpected oxidation upon treatment with a strong reducing agent was reproduced by us (vide infra) in the cases of $\mathbf{1}$ and $\mathbf{6}$ without excluding air. It seems likely that the strong base abstracts the $\mathrm{C}-12 \mathrm{~b}$ proton, leading to attack by oxygen at this position, but we still lack an explanation for the unsuccessful reduction of the carbonyl group under these conditions.

In order to carry out preliminary pharmacological studies on $5,6,8,12 \mathrm{~b}$ tetrahydroisoindolo[1,2- $a$ ] isoquinolin-8-ones, we required a limited series of compounds that could provide tentative structure-activity relationships and guide future synthetic endeavors. Owing to its simplicity, economy and generally satisfactory yields, we chose the methodology originally described for the synthesis of $( \pm)$-10,11-dimethoxy-5,6,8,12b-tetrahydroisoindolo[1,2-a] isoquinolin-8-one, ${ }^{5}$ and used in our laboratory to prepare $1 .^{6}$ This approach relies on the borohydride reduction of $N$-phenylethylphthalimides and subsequent cyclization of the resulting 1-hydroxyisoindolin-3-ones with $37 \%$ hydrochloric acid. As stated above, these compounds can subsequently be oxidized at $\mathrm{C}-12 \mathrm{~b}$ by bubbling air through a basic solution, providing a route to $12 \mathrm{~b}$-hydroxylated derivatives. In principle, these 12b-hydroxy compounds can undergo nucleophilic substitution of the hydroxyl group, generating a wide variety of novel substances, many of which can be expected to be of pharmacological interest.

\section{RESULTS AND DISCUSSION}

All our syntheses began with the preparation of $N$-phenethylphthalimides in yields usually exceeding $80-90 \%$ from phenylethylamine or appropriately substituted derivatives. The latter were obtained in all cases by HenryKnoevenagel condensation of the corresponding benzaldehydes with nitromethane and lithium aluminium hydride reduction of the resulting $\beta$-nitrostyrenes. Subsequent reduction to the 3-hydroxy-2-(2-phenylethyl) isoindolin-1-ones (a1-a13) was achieved in approximately $90 \%$ yields using sodium borohydride in refluxing $\mathrm{MeOH}$-dioxane. The final cyclization was carried out using concentrated $\mathrm{HCl}$, obtaining similar results to those obtained with trifluoroacetic acid, affording ( \pm )-4,5,8,12b-tetrahydroisoindolo[1,2- $a]$ isoquinolin-8-one (1) and a series of its A-ring substituted derivatives (2-11) in moderate to good yields ( $42-80 \%)$, as well as a few representative $12 \mathrm{~b}$-hydroxy derivatives $(\mathbf{1 A}, \mathbf{4 A}, \mathbf{6 A})$. The whole sequence is shown in Scheme 15.
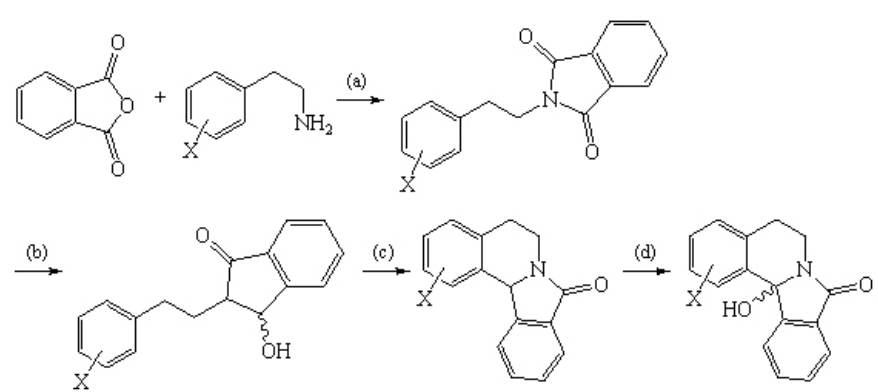

Scheme 15. Reagents and conditions: (a) $\mathrm{EtOH}, 80^{\circ} \mathrm{C}$; (b) $\mathrm{NaBH}_{4}, \mathrm{MeOH}$ / dioxane (1:1), reflux, $3 \mathrm{~h}$; (c) $37 \% \mathrm{HCl}$, reflux, $1 \mathrm{~h}$; (d) $0.5 \mathrm{M} \mathrm{KOH} / \mathrm{MeOH}$, air, reflux, $24 \mathrm{~h}$.
The compounds reported here are summarized in Table 1.

Table 1. Structures of the $( \pm)-5,6,8,12 \mathrm{~b}$-tetrahydroisoindolo[ $[1,2-a]$ isoquinolin-8-ones reported in this paper.

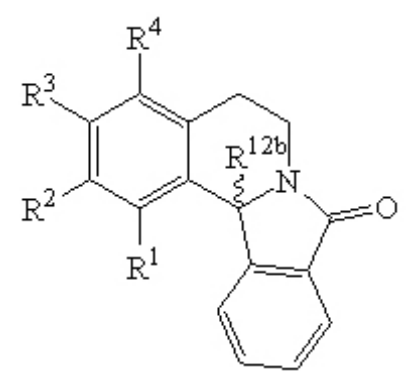

$1 \quad \mathrm{R}^{1}=\mathrm{R}^{2}=\mathrm{R}^{3}=\mathrm{R}^{4}=\mathrm{R}^{12 \mathrm{~b}}=\mathrm{H}$

1A $\mathrm{R}^{1}=\mathrm{R}^{2}=\mathrm{R}^{3}=\mathrm{R}^{4}=\mathrm{H} ; \mathrm{R}^{12 b}=\mathrm{OH}$

$2 \quad \mathrm{R}^{1}=\mathrm{R}^{2}=\mathrm{R}^{3}=\mathrm{H} ; \mathrm{R}^{4}=\mathrm{OMe} ; \mathrm{R}^{12 \mathrm{~b}}=\mathrm{H}$

$3 \quad \mathrm{R}^{1}=\mathrm{R}^{2}=\mathrm{R}^{4}=\mathrm{H} ; \mathrm{R}^{3}=\mathrm{OMe} ; \mathrm{R}^{12 \mathrm{~b}}=\mathrm{H}$

$4 \quad \mathrm{R}^{1}=\mathrm{R}^{3}=\mathrm{R}^{4}=\mathrm{H} ; \mathrm{R}^{2}=\mathrm{OMe} ; \mathrm{R}^{12 \mathrm{~b}}=\mathrm{H}$

4A $\quad \mathrm{R}^{1}=\mathrm{R}^{3}=\mathrm{R}^{4}=\mathrm{H} ; \mathrm{R}^{2}=\mathrm{OMe} ; \mathrm{R}^{12 \mathrm{~b}}=\mathrm{OH}$

$5 \quad \mathrm{R}^{1}=\mathrm{R}^{2}=\mathrm{H} ; \mathrm{R}^{3}=\mathrm{R}^{4}=\mathrm{OMe} ; \mathrm{R}^{12 \mathrm{~b}}=\mathrm{H}$

$6 \quad \mathrm{R}^{1}=\mathrm{R}^{4}=\mathrm{H} ; \mathrm{R}^{2}=\mathrm{R}^{3}=\mathrm{OMe} ; \mathrm{R}^{12 b}=\mathrm{H}$

6A $\quad \mathrm{R}^{1}=\mathrm{R}^{4}=\mathrm{H} ; \mathrm{R}^{2}=\mathrm{R}^{3}=\mathrm{OMe} ; \mathrm{R}^{12 \mathrm{~b}}=\mathrm{OH}$

$7 \quad \mathrm{R}^{1}=\mathrm{R}^{4}=\mathrm{OMe} ; \mathrm{R}^{2}=\mathrm{R}^{3}=\mathrm{H} ; \mathrm{R}^{12 \mathrm{~b}}=\mathrm{H}$

$8 \quad \mathrm{R}^{1}=\mathrm{R}^{2}=\mathrm{R}^{3}=\mathrm{OMe} ; \mathrm{R}^{4}=\mathrm{H} ; \mathrm{R}^{12 \mathrm{~b}}=\mathrm{H}$

$9 \quad \mathrm{R}^{1}=\mathrm{R}^{4}=\mathrm{H} ; \mathrm{R}^{2}=\mathrm{OMe} ; \mathrm{R}^{3}=\mathrm{OH} ; \mathrm{R}^{12 \mathrm{~b}}=\mathrm{H}$

$10 \quad \mathrm{R}^{1}=\mathrm{R}^{4}=\mathrm{H} ; \mathrm{R}^{2}=\mathrm{OH} ; \mathrm{R}^{3}=\mathrm{OMe} ; \mathrm{R}^{12 b}=\mathrm{H}$

$11 \quad \mathrm{R}^{1}=\mathrm{R}^{4}=\mathrm{H} ; \mathrm{R}^{2}+\mathrm{R}^{3}=\mathrm{OCH}_{2} \mathrm{O} ; \mathrm{R}^{12 \mathrm{~b}}=\mathrm{H}$

$12 \mathrm{R}^{1}=\mathrm{R}^{4}=\mathrm{H} ; \mathrm{R}^{2}=\mathrm{R}^{3}=\mathrm{OH} ; \mathrm{R}^{12 b}=\mathrm{H}$

Attempts to cyclize 3-hydroxy-2-[2-(4-dimethylaminophenyl)ethyl] isoindolin-1-one (l) under these conditions were unsuccessful, possibly because of the deactivation of the aromatic ring for electrophilic substitution as a consequence of protonation of the amine group in the strongly acid media required to generate the reactive acyliminium ion intermediate. ${ }^{8}$ The loss of the benzyl group upon cyclization of $\mathbf{i}$ and $\mathbf{j}$ to $\mathbf{9}$ and 10, respectively, was expected under the strongly acid conditions used. 2,3-Dimethoxy-4,5,8,12btetrahydroisoindolo[1,2- $a$ ] isoquinolin-8-one (6) was converted to the corresponding catechol (12) by treatment with boron tribromide.

The extremely facile and quantitative autoxidation of $4,5,8,12$ b-tetrahydroisoindolo[1,2-a]isoquinolin-8-one to its $12 \mathrm{~b}$-hydroxy derivative (1A) and the analogous preparation of the 2-methoxy and 2,3 -dimethoxy analogues $(\mathbf{4 A}, 87 \% ; \mathbf{6 A}, 56 \%$ yield $)$, similarly to the report of the formation of this product under lithium aluminium hydride reduction conditions, ${ }^{4}$ and for 10,11-dimethoxy-5,6,8,12b-tetrahydroisoindolo[1,2- $\left.a\right]$ isoquinolin-8-one under conditions resembling those used by us $(90 \%$ crude yield), ${ }^{5}$ deserves some comment. C-12b is doubly benzylic and should therefore generate a highly stabilized free radical (II) upon hydrogen abstraction. However, the preferred use of strongly alkaline conditions suggests that the mechanism of autoxidation in this case might proceed via ionization to afford a carbanion (I) capable of reducing molecular oxygen, thus becoming oxidized to the doubly benzylic radical II. Benzyl carbanions are not expected to be particularly stable unless properly situated, strongly electron-withdrawing substituents are present. In this case the lactam carbonyl group might fulfil this role, while the electron-donating groups in the methoxy derivatives, particularly on ring A which is not conjugated with the carbonyl, might explain the lower yields obtained. On the other hand, the facile nucleophilic substitutions at hydroxyl-substituted C-12b imply the formation of a highly stabilized $N$-acyliminium ion (III). 


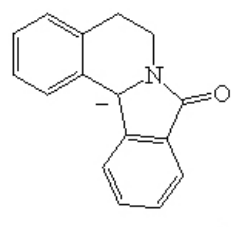

I
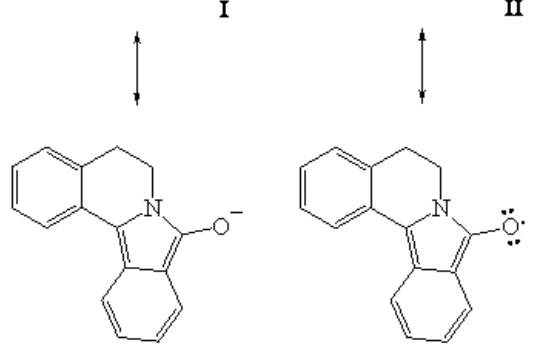

II
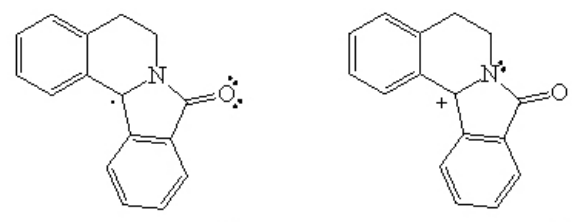

III

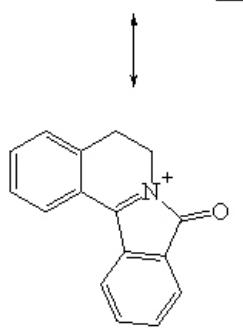

More detailed structure-reactivity studies certainly seem to be warranted in the 5,6,8,12b-tetrahydroisoindolo[1,2-a]isoquinolin-8-one system.

Lithium aluminium hydride reduction of $\mathbf{1}$ and $\mathbf{6}$ in the presence of air was unsuccessful, affording only the 12b-hydroxy derivatives $\mathbf{1 A}$ and $\mathbf{6 A}$ as isolable products. In the experimental section only the attempted reduction of 6 with formation of $\mathbf{6 A}$ is described, while the preparation of $1 \mathrm{~A}$ and $\mathbf{4 A}$ is reported using the high-yield air oxidation.

To summarize, ( \pm )-5,6,8,12b-tetrahydroisoindolo[1,2-a]isoquinolin-8one (1) and eleven derivatives (2-12) bearing one to three methoxyl groups, a methylenedioxy group, a methoxyl and a hydroxyl, or two hydroxyl groups on ring $\mathrm{A}$, as well as three compounds oxidized at $\mathrm{C}-12 \mathrm{~b}(\mathbf{1} \mathbf{A}, \mathbf{4 A}$, 6A) were synthesized, most of them for the first time, in moderate to good yields. The general synthetic route involved acid-catalyzed cyclization of the corresponding 3-hydroxy-2-(substituted phenyl)ethylisoindol-1-ones or $O$-benzyl-protected precursors or, in one instance, by $O$-demethylation of one of the former products.

\section{EXPERIMENTAL SECTION}

General Procedures. Commercially available, laboratory grade reagents were used without further purification. Melting points were determined on a Reichert Galen III hot plate with a with a DUAL JTEK Dig - Sense thermocouple thermometer, and are uncorrected. The ${ }^{1} \mathrm{H}$ and ${ }^{13} \mathrm{C}$ NMR spectra were recorded on Bruker Avance spectrometers at 300 or $400 \mathrm{MHz}$ and 75 or $100 \mathrm{MHz}$, respectively, using $\mathrm{CDCl}_{3}$ as solvent unless indicated otherwise. The chemical shifts are reported as ppm downfield from TMS. Analytical TLC was performed on Merck silica gel $60 \mathrm{~F}_{254}$ chromatofoils.

The substituted precursor benzaldehydes were purchased from Aldrich or prepared in greater than $90 \%$ yield by $O$-benzylation of 4-hydroxy-3methoxybenzaldehyde and 3-hydroxy-4-methoxybenzaldehyde, respectively. The benzaldehydes were converted to the corresponding $\beta$-nitrostyrenes (Henry-Knoevenagel condensation with nitromethane) in acetic acid using cyclohexylamine or ammonium acetate as base. After purification by crystallization, the reaction products were reduced to the amines with $\mathrm{LiAlH}_{4}$. The $N$-phenylethylphthalimides were prepared by heating an equimolar mixture of each amine, recently distilled under reduced pressure, with phthalic anhydride at $100-150{ }^{\circ} \mathrm{C}$ for at least $1 \mathrm{~h}$, purified by recrystallization in $\mathrm{MeOH}$ and characterized by ${ }^{1} \mathrm{H}$ NMR. The 2-phenylethyl-3-hydroxyisoindolin-1ones $(\mathbf{a}-\mathbf{k})$ were obtained by slow addition of $\mathrm{NaBH}_{4}$ (1.5:1 molar ratio) to the phthalimides in dioxane- $\mathrm{MeOH}\left(1: 1,0{ }^{\circ} \mathrm{C}, 30 \mathrm{~min}\right)$, followed by gentle reflux for 3 hours. The volume was reduced to about one half on a rotary evaporator, and water was added to the hot solution. After cooling, the resulting precipitate was filtered off, washed with distilled water and dried to give the desired product as colorless needles from $\mathrm{MeOH}$. The cyclization to afford the 4,5,8,12b-tetrahydroisoindolo[1,2-a]isoquinolin-8-ones (1-11) was carried out by refluxing for $1 \mathrm{~h}$ with $37 \% \mathrm{HCl}$. The reaction mixture was brought to room temperature and poured into ice-water giving a precipitate that was washed with water, dried and recrystallized to yield 1-11. Only 2-methoxy4,5,8,12b-tetrahydroisoindolo[1,2-a] isoquinolin-8-one (4) had to be purified by chromatography on Merck silica gel 60, 230-400 mesh $\left(\mathrm{MeOH} / \mathrm{CH}_{2} \mathrm{Cl}_{2}\right.$, 2:8).
3-Hydroxy-2-(2-phenylethyl)isoindolin-1-one (a). Colorless needles from $\mathrm{MeOH}(96 \%)$, mp $170-172{ }^{\circ} \mathrm{C}$ (lit. $\left.{ }^{25} 166-168{ }^{\circ} \mathrm{C}\right) .{ }^{1} \mathrm{H}$ NMR $(300 \mathrm{MHz})$ : $\delta 2.98\left(\mathrm{~m}, 2 \mathrm{H}, \mathrm{CH}_{2}\right), 3.63\left(\mathrm{~m}, 2 \mathrm{H}, \mathrm{CH}_{2}\right), 5.52(\mathrm{~s}, 1 \mathrm{H}, \mathrm{CH}), 6.43(\mathrm{~s}, 1 \mathrm{H}, \mathrm{OH})$ $7.22(\mathrm{~m}, 5 \mathrm{H}, \mathrm{ArH}), 7.60(\mathrm{~m}, 4 \mathrm{H}, \mathrm{ArH})$

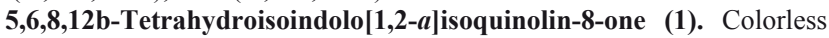
plates from EtOAc (77\%), mp 115-117 ${ }^{\circ} \mathrm{C}$ (lit. ${ }^{3,4,11} 114-116,116-118,114-116$ $\left.{ }^{\circ} \mathrm{C}\right) .{ }^{1} \mathrm{H}$ NMR (400 MHz): $\delta 2.88\left(\mathrm{~m}, 1 \mathrm{H}, \mathrm{CH}_{2}\right), 3.05\left(\mathrm{~m}, 1 \mathrm{H}, \mathrm{CH}_{2}\right), 3.48(\mathrm{~m}$, $\left.1 \mathrm{H}, \mathrm{CH}_{2}\right), 4.42\left(\mathrm{~m}, 1 \mathrm{H}, \mathrm{CH}_{2}\right), 5.65(\mathrm{~s}, 1 \mathrm{H}, \mathrm{CH}), 7.18(\mathrm{t}, J=7.1 \mathrm{~Hz}, 1 \mathrm{H}, \mathrm{ArH})$, $7.22(\mathrm{t}, J=7.1 \mathrm{~Hz}, 1 \mathrm{H}, \mathrm{ArH}), 7.27(\mathrm{t}, J=7.1 \mathrm{~Hz}, 1 \mathrm{H}, \mathrm{ArH}), 7.48(\mathrm{t}, J=7.6$ $\mathrm{Hz}, 1 \mathrm{H}, \mathrm{ArH}), 7.61$ (m, 2H, ArH), $7.86(\mathrm{~d}, J=7.6 \mathrm{~Hz}, 1 \mathrm{H}, \mathrm{ArH}), 7.87$ (d, $J=$ $7.1 \mathrm{~Hz}, 1 \mathrm{H}, \mathrm{ArH})$

12b-Hydroxy-5,6,8,12b-tetrahydroisoindolo[1,2-a]isoquinolin-8-one (1A). $1(5.0 \mathrm{~g}, 21 \mathrm{mmole})$ in $0.5 \mathrm{M} \mathrm{KOH} / \mathrm{MeOH}(60 \mathrm{~mL})$ was oxidized with air (bubbling, reflux, $24 \mathrm{~h}$ ). The solution was concentrated and water was added to generate a precipitate which was collected by filtration, washed with water, dried and crystallized in $\mathrm{MeOH}$ to give white needles (5.3 g, $99 \%$ ). Off-white plates, mp 197-198 ${ }^{\circ} \mathrm{C}$ (lit. $\left.{ }^{4} 200-203{ }^{\circ} \mathrm{C}\right) .{ }^{1} \mathrm{H}$ NMR $(400 \mathrm{MHz}): \delta 2.83(\mathrm{~m}, 1 \mathrm{H}$, $\left.\mathrm{CH}_{2}\right), 2.97\left(\mathrm{~m}, 1 \mathrm{H}, \mathrm{CH}_{2}\right), 3.45\left(\mathrm{~m}, 1 \mathrm{H}, \mathrm{CH}_{2}\right), 4.07(\mathrm{~s}, 1 \mathrm{H}, \mathrm{OH}), 4.17(\mathrm{~m}, 1 \mathrm{H}$, $\left.\mathrm{CH}_{2}\right), 7.13(\mathrm{~d}, J=7.4 \mathrm{~Hz}, 1 \mathrm{H}, \mathrm{ArH}), 7.23(\mathrm{~d}, J=7.0 \mathrm{~Hz}, 1 \mathrm{H}, \mathrm{ArH}), 7.29(\mathrm{t}$, $J=7.2 \mathrm{~Hz}, 1 \mathrm{H}, \mathrm{ArH}), 7.46(\mathrm{t}, J=7.6 \mathrm{~Hz}, 1 \mathrm{H}, \mathrm{ArH}), 7.62(\mathrm{t}, J=7.6 \mathrm{~Hz}, 1 \mathrm{H}$, ArH), 7.67 (d, $J=7.6 \mathrm{~Hz}, 1 \mathrm{H}, \mathrm{ArH}), 7.94$ (d, $J=7.6 \mathrm{~Hz}, 1 \mathrm{H}, \mathrm{ArH}), 8.3$ (d, $J$ $=7.6 \mathrm{~Hz}, 1 \mathrm{H}, \mathrm{ArH})$

3-Hydroxy-2-[2-(2-methoxyphenyl)ethyl]isoindolin-1-one

(b). Colorless needles from $\mathrm{MeOH}(81 \%), \mathrm{mp} 106^{\circ} \mathrm{C} .{ }^{1} \mathrm{H}$ NMR (400 MHz): $\delta 2.98$ $\left(\mathrm{m}, 2 \mathrm{H}, \mathrm{CH}_{2}\right), 3.75\left(\mathrm{~s}, 3 \mathrm{H}, \mathrm{OCH}_{3}\right), 3.92\left(\mathrm{~m}, 2 \mathrm{H}, \mathrm{CH}_{2}\right), 5.61(\mathrm{~s}, 1 \mathrm{H}, \mathrm{CH}), 6.13$ $(\mathrm{s}, 1 \mathrm{H}, \mathrm{OH}), 6.79(\mathrm{~m}, 2 \mathrm{H}, \mathrm{ArH}), 7.06(\mathrm{~d}, J=7.2 \mathrm{~Hz}, 2 \mathrm{H}, \mathrm{ArH}), 7.13(\mathrm{t}, J=7.6$ $\mathrm{Hz}, 1 \mathrm{H}, \mathrm{ArH}), 7.32(\mathrm{~m}, 2 \mathrm{H}, \mathrm{ArH}), 7.48(\mathrm{~d}, J=7.4 \mathrm{~Hz}, 1 \mathrm{H}, \mathrm{ArH}), 7.82(\mathrm{~d}, J=$ $7.3 \mathrm{~Hz}, 1 \mathrm{H}, \mathrm{ArH})$.

4-Methoxy-5,6,8,12b-tetrahydroisoindolo[1,2-a]isoquinolin-8-one (2). Colorless needles from $\mathrm{MeOH}(66 \%), \mathrm{mp} 150-151^{\circ} \mathrm{C} .{ }^{1} \mathrm{H}$ NMR $(400 \mathrm{MHz}): \delta$ $2.89\left(\mathrm{~m}, 2 \mathrm{H}, \mathrm{CH}_{2}\right), 3.37\left(\mathrm{~m}, 1 \mathrm{H}, \mathrm{CH}_{2}\right), 3.81\left(\mathrm{~s}, 3 \mathrm{H}, \mathrm{OCH}_{3}\right), 4.54\left(\mathrm{~m}, 1 \mathrm{H}, \mathrm{CH}_{2}\right)$, $5.68(\mathrm{~s}, 1 \mathrm{H}, \mathrm{CH}), 7.77(\mathrm{~d}, J=7.3 \mathrm{~Hz}, 1 \mathrm{H}, \mathrm{ArH}), 7.27(\mathrm{~m}, 2 \mathrm{H}, \mathrm{ArH}), 7.48(\mathrm{t}$, $J=7.4 \mathrm{~Hz}, 1 \mathrm{H}, \mathrm{ArH}), 7.59(\mathrm{t}, J=7.3 \mathrm{~Hz}, 1 \mathrm{H}, \mathrm{ArH}), 7.86(\mathrm{~d}, J=8.1 \mathrm{~Hz}, 2 \mathrm{H}$, $\mathrm{ArH})$.

3-Hydroxy-2-[2-(3-methoxyphenyl)ethyl]isoindolin-1-one(c). Colorless needles from $\mathrm{MeOH}(81 \%), \mathrm{mp} 132-133{ }^{\circ} \mathrm{C} .{ }^{1} \mathrm{H}$ NMR $(400 \mathrm{MHz}): \delta 3.02(\mathrm{~m}$, $\left.2 \mathrm{H}, \mathrm{CH}_{2}\right), 3.75\left(\mathrm{~s}, 3 \mathrm{H}, \mathrm{OCH}_{3}\right), 3.95\left(\mathrm{~m}, 2 \mathrm{H}, \mathrm{CH}_{2}\right), 5.66(\mathrm{~s}, 1 \mathrm{H}, \mathrm{CH}), 6.22(\mathrm{~s}$, $1 \mathrm{H}, \mathrm{OH}), 6.78(\mathrm{~d}, J=7.9 \mathrm{~Hz}, 1 \mathrm{H}, \mathrm{ArH}), 6.80(\mathrm{~s}, 1 \mathrm{H}, \mathrm{ArH}), 6.89(\mathrm{~d}, J=7.8$ $\mathrm{Hz}, 1 \mathrm{H}, \mathrm{ArH}), 7.18(\mathrm{t}, J=7.6 \mathrm{~Hz}, 1 \mathrm{H}, \mathrm{ArH}), 7.29(\mathrm{t}, J=7.6 \mathrm{~Hz}, 1 \mathrm{H}, \mathrm{ArH})$ $7.34(\mathrm{t}, J=7.8 \mathrm{~Hz}, 1 \mathrm{H}, \mathrm{ArH}), 7.52(\mathrm{~d}, J=7.2 \mathrm{~Hz}, 1 \mathrm{H}, \mathrm{ArH}), 7.76(\mathrm{~d}, J=7.3$ $\mathrm{Hz}, 1 \mathrm{H}, \mathrm{ArH})$

3-Methoxy-5,6,8,12b-tetrahydroisoindolo[1,2-a]isoquinolin-8-one (3). Yellow oil $(66 \%){ }^{1} \mathrm{H}$ NMR $(400 \mathrm{MHz}): \delta 2.83\left(\mathrm{~m}, 1 \mathrm{H}, \mathrm{CH}_{2}\right), 3.02(\mathrm{~m}, 1 \mathrm{H}$, $\left.\mathrm{CH}_{2}\right), 3.45\left(\mathrm{~m}, 1 \mathrm{H}, \mathrm{CH}_{2}\right), 3.76\left(\mathrm{~s}, 3 \mathrm{H}, \mathrm{OCH}_{3}\right), 4.39\left(\mathrm{~m}, 1 \mathrm{H}, \mathrm{CH}_{2}\right), 5.58(\mathrm{~s}, 1 \mathrm{H}$, $\mathrm{CH}), 6.70(\mathrm{~d}, J=2.2 \mathrm{~Hz}, 1 \mathrm{H}, \mathrm{ArH}), 6.81\left(\mathrm{dd}, J_{1}=2.5 \mathrm{~Hz}, J=8.6 \mathrm{~Hz}, 1 \mathrm{H}, \mathrm{ArH}\right)$, $7.46(\mathrm{~d}, J=7.4 \mathrm{~Hz}, 1 \mathrm{H}, \mathrm{ArH}), 7.50(\mathrm{~d}, J=8.6 \mathrm{~Hz}, 1 \mathrm{H}, \mathrm{ArH}), 7.58(\mathrm{t}, J=7.6 \mathrm{~Hz}$, $1 \mathrm{H}, \mathrm{ArH}), 7.81$ (d, $J=7.6 \mathrm{~Hz}, 1 \mathrm{H}, \mathrm{ArH}), 7.86(\mathrm{~d}, J=7.6 \mathrm{~Hz}, 1 \mathrm{H}, \mathrm{ArH})$.

3-Hydroxy-[2-(4-Methoxyphenyl)ethyl]isoindolin-1-one (d). Colorless needles from $\mathrm{MeOH}(92 \%), \mathrm{mp} 113-114{ }^{\circ} \mathrm{C} .{ }^{1} \mathrm{H}$ NMR (300 MHz): $\delta 2.91(\mathrm{~m}$, $\left.2 \mathrm{H}, \mathrm{CH}_{2}\right), 3.79\left(\mathrm{~s}, 3 \mathrm{H}, \mathrm{OCH}_{3}\right), 3.69\left(\mathrm{~m}, 2 \mathrm{H}, \mathrm{CH}_{2}\right), 5.52(\mathrm{~s}, 1 \mathrm{H}, \mathrm{CH}), 6.37(\mathrm{~s}, 1 \mathrm{H}$, $\mathrm{OH}), 6.80(\mathrm{~d}, J=8.6 \mathrm{~Hz}, 2 \mathrm{H}, \mathrm{ArH}), 6.86(\mathrm{~d}, J=8.6 \mathrm{~Hz}, 2 \mathrm{H}, \mathrm{ArH}), 7.15(\mathrm{~m}, 2 \mathrm{H}$, $\mathrm{ArH}), 7.54$ (d, $J=7.6 \mathrm{~Hz}, 1 \mathrm{H}, \mathrm{ArH}), 7.68$ (d, $J=7.4 \mathrm{~Hz}, 1 \mathrm{H}, \mathrm{ArH})$.

2-Methoxy-5,6,8,12b-tetrahydroisoindolo[1,2-a]isoquinolin-8-one (4). Colorless needles from $\mathrm{MeOH}(48 \%), \mathrm{mp} 129-130{ }^{\circ} \mathrm{C}$ (lit. ${ }^{11}$ yellow oil). ${ }^{1} \mathrm{H}$ NMR (400 MHz): $\delta 2.90\left(\mathrm{~m}, 2 \mathrm{H}, \mathrm{CH}_{2}\right), 3.46\left(\mathrm{~m}, 1 \mathrm{H}, \mathrm{CH}_{2}\right), 3.82\left(\mathrm{~s}, 3 \mathrm{H}, \mathrm{OCH}_{2}\right)$, $4.39\left(\mathrm{~m}, 1 \mathrm{H}, \mathrm{CH}_{2}\right), 5.62(\mathrm{~s}, 1 \mathrm{H}, \mathrm{CH}), 6.79\left(\mathrm{dd}, J_{1}=2.7 \mathrm{~Hz}, J_{2}=8.6 \mathrm{~Hz}, 1 \mathrm{H}\right.$, $\mathrm{ArH}), 7.12(\mathrm{~m}, 2 \mathrm{H}, \mathrm{ArH}), 7.49(\mathrm{t}, J=7.6 \mathrm{~Hz}, 1 \mathrm{H}, \mathrm{ArH}), 7.61(\mathrm{t}, J=7.4 \mathrm{~Hz}, 1 \mathrm{H}$, $\mathrm{ArH}), 7.84$ (m, 2H, $\mathrm{ArH})$.

$12 \mathrm{~b}-\mathrm{Hydroxy}-2$-methoxy-5,6,8,12b-tetrahydroisoindolo $[1,2-a]$ isoquinolin-8-one $(4 \mathrm{~A})$. Following the procedure used to prepare $1 \mathrm{~A}, 4 \mathrm{~A}$ was obtained as beige crystals from $\mathrm{MeOH}(87 \%), \mathrm{mp} 184-185^{\circ} \mathrm{C}$. ${ }^{1} \mathrm{H}$ NMR $(400$ MHz): $\delta 2.80\left(\mathrm{~m}, 1 \mathrm{H}, \mathrm{CH}_{2}\right), 2.97\left(\mathrm{~m}, 1 \mathrm{H}, \mathrm{CH}_{2}\right), 3.46\left(\mathrm{~m}, 1 \mathrm{H}, \mathrm{CH}_{2}\right), 3.84(\mathrm{~s}, 3 \mathrm{H}$, $\left.\mathrm{OCH}_{3}\right), 4.32\left(\mathrm{~m}, 1 \mathrm{H}, \mathrm{CH}_{2}\right), 6.81\left(\mathrm{dd}, J=8.4 \mathrm{~Hz}, J^{\prime}=2.4 \mathrm{~Hz}, 1 \mathrm{H}, \mathrm{ArH}\right), 7.09$ $(\mathrm{d}, J=8.4 \mathrm{~Hz}, 1 \mathrm{H}, \mathrm{ArH}), 7.48(\mathrm{~d}, J=2.5 \mathrm{~Hz}, 1 \mathrm{H}, \mathrm{ArH}), 7.51(\mathrm{t}, J=7.6 \mathrm{~Hz}, 1 \mathrm{H}$, $\mathrm{ArH}), 7.64(\mathrm{t}, J=7.6 \mathrm{~Hz}, 1 \mathrm{H}, \mathrm{ArH}), 7.72(\mathrm{~d}, J=7.6 \mathrm{~Hz}, 1 \mathrm{H}, \mathrm{ArH}), 8.04(\mathrm{~d}, J$ $=7.6 \mathrm{~Hz}, 1 \mathrm{H}, \mathrm{ArH})$

3-Hydroxy-[2-(2,3-Dimethoxyphenyl)ethyl]isoindolin-1-one (e). Colorless needles from $\mathrm{MeOH}(89 \%), \mathrm{mp} 168-170{ }^{\circ} \mathrm{C} .{ }^{1} \mathrm{H}$ NMR $(400 \mathrm{MHz}): \delta$ $2.99\left(\mathrm{~m}, 2 \mathrm{H}, \mathrm{CH}_{2}\right), 3.77\left(\mathrm{~m}, 2 \mathrm{H}, \mathrm{CH}_{2}\right), 3.88\left(\mathrm{~s}, 3 \mathrm{H}, \mathrm{OCH}_{3}\right), 3.95\left(\mathrm{~s}, 3 \mathrm{H}, \mathrm{OCH}_{3}\right)$ $5.26(\mathrm{~s}, 1 \mathrm{H}, \mathrm{CH}), 6.39(\mathrm{~s}, 1 \mathrm{H}, \mathrm{OH}), 6.73(\mathrm{t}, J=7.1 \mathrm{~Hz}, 2 \mathrm{H}, \mathrm{ArH}), 6.89(\mathrm{t}, J=$ $7.6 \mathrm{~Hz}, 1 \mathrm{H}, \mathrm{ArH}), 7.20(\mathrm{~m}, 2 \mathrm{H}, \mathrm{ArH}), 7.56(\mathrm{~d}, J=7.5 \mathrm{~Hz}, 1 \mathrm{H}, \mathrm{ArH}), 7.70(\mathrm{~d}$, $J=7.4 \mathrm{~Hz}, 1 \mathrm{H}, \mathrm{ArH})$

3,4-Dimethoxy-5,6,8,12b-tetrahydroisoindolo $[1,2-a]$ isoquinolin-8-one 
(5). Colorless needles from $\mathrm{MeOH}(62 \%), \mathrm{mp} 130-131{ }^{\circ} \mathrm{C} .{ }^{1} \mathrm{H}$ NMR $(300$ $\mathrm{MHz}): \delta 3.01\left(\mathrm{~m}, 2 \mathrm{H}, \mathrm{CH}_{2}\right), 3.43\left(\mathrm{~m}, 1 \mathrm{H}, \mathrm{CH}_{2}\right), 3.78\left(\mathrm{~s}, 3 \mathrm{H}, \mathrm{OCH}_{3}\right), 3.85(\mathrm{~s}$, $\left.3 \mathrm{H}, \mathrm{OCH}_{3}\right), 4.44\left(\mathrm{~m}, 1 \mathrm{H}, \mathrm{CH}_{2}\right), 5.62(\mathrm{~s}, 1 \mathrm{H}, \mathrm{CH}), 6.67(\mathrm{~d}, J=8.7 \mathrm{~Hz}, 1 \mathrm{H}, \mathrm{ArH})$, $7.33(\mathrm{~d}, J=8.5 \mathrm{~Hz}, 1 \mathrm{H}, \mathrm{ArH}), 7.49(\mathrm{t}, J=7.4 \mathrm{~Hz}, 1 \mathrm{H}, \mathrm{ArH}), 7.60(\mathrm{t}, J=6.6 \mathrm{~Hz}$, $1 \mathrm{H}, \mathrm{ArH}), 7.83$ (d, $J=7.7 \mathrm{~Hz}, 1 \mathrm{H}, \mathrm{ArH}), 7.87$ (d, $J=7.5 \mathrm{~Hz}, 1 \mathrm{H}, \mathrm{ArH})$.

3-Hydroxy[2-(3,4-dimethoxyphenyl)ethyl]isoindolin-1-one Colorless needles from $\mathrm{MeOH}(95 \%)$, mp $141^{\circ} \mathrm{C}$ (lit. $\left.{ }^{25} 138-140{ }^{\circ} \mathrm{C}\right) .{ }^{1} \mathrm{H}$ NMR $\left(300 \mathrm{MHz}, \mathrm{DMSO}-d_{\mathrm{s}}\right): \delta 2.85\left(\mathrm{~m}, 2 \mathrm{H}, \mathrm{CH}_{2}\right), 3.68\left(\mathrm{~s}, 3 \mathrm{H}, \mathrm{OCH}_{3}\right), 3.70(\mathrm{~s}, 3 \mathrm{H}$, $\left.\mathrm{OCH}_{3}\right), 3.80\left(\mathrm{~m}, 2 \mathrm{H}, \mathrm{CH}_{2}\right), 5.72(\mathrm{~s}, 1 \mathrm{H}, \mathrm{CH}), 6.76(\mathrm{~m}, 3 \mathrm{H}, \mathrm{ArH}), 7.59(\mathrm{~m}, 4 \mathrm{H}$, $\operatorname{ArH})$.

2,3-Dimethoxy-5,6,8,12b-tetrahydroisoindolo[1,2-a]isoquinolin-8-one (6). Colorless needles from $\mathrm{MeOH}(63 \%), \mathrm{mp} 165^{\circ} \mathrm{C}$. (lit. ${ }^{13,18,11} 173,164-166$, 172-173 $\left.{ }^{\circ} \mathrm{C}\right){ }^{1} \mathrm{H}$ NMR $(400 \mathrm{MHz}): \delta 2.76\left(\mathrm{~m}, 1 \mathrm{H}, \mathrm{CH}_{2}\right), 3.01\left(\mathrm{~m}, 1 \mathrm{H}, \mathrm{CH}_{2}\right)$, $3.43\left(\mathrm{~m}, 1 \mathrm{H}, \mathrm{CH}_{2}\right), 3.85\left(\mathrm{~s}, 3 \mathrm{H}, \mathrm{OCH}_{3}\right), 3.93\left(\mathrm{~s}, 3 \mathrm{H}, \mathrm{OCH}_{3}\right), 4.50\left(\mathrm{~m}, 1 \mathrm{H}, \mathrm{CH}_{2}\right)$, $5.62(\mathrm{~s}, 1 \mathrm{H}, \mathrm{CH}), 6.67(\mathrm{~s}, 1 \mathrm{H}, \mathrm{ArH}), 7.13(\mathrm{~s}, 1 \mathrm{H}, \mathrm{ArH}), 7.50(\mathrm{t}, J=7.6 \mathrm{~Hz}, 1 \mathrm{H}$, $\operatorname{ArH}), 7.61(\mathrm{t}, J=7.6 \mathrm{~Hz}, 1 \mathrm{H}, \mathrm{ArH}), 7.83(\mathrm{~d}, J=7.8 \mathrm{~Hz}, 1 \mathrm{H}, \mathrm{ArH}), 7.88(\mathrm{~d}, J$ $=7.6 \mathrm{~Hz}, 1 \mathrm{H}, \mathrm{ArH})$.

2,3-Dimethoxy-12b-hydroxy-5,6,8,12b-tetrahydroisoindolo[1,2-a] isoquinolin-8-one (6A). 6 (1.0 g, 3.4 mmole) in anhydrous THF $(25 \mathrm{~mL})$ was added dropwise to a well stirred and refluxing solution of $\mathrm{LiAlH}_{4}(1.0 \mathrm{~g}, 26$ mmole) in THF $(50 \mathrm{~mL})$ without excluding air. The reaction mixture was held at reflux temperature for $48 \mathrm{~h}$, after which, once cooled to room temperature, the excess hydride was destroyed by adding water-THF $(1: 1,14 \mathrm{~mL})$ followed by $15 \% \mathrm{NaOH}(7 \mathrm{~mL})$ and then again water $(10 \mathrm{~mL})$. The solids were removed by filtration and washed with additional THF. The combined filtrate and washes were stripped of solvent under vacuum, and the residue was chromatographed on silica gel (EtOAc) to afford $\mathbf{6 A}(0.59 \mathrm{~g}, 56 \%)$ as colorless prisms from $\mathrm{MeOH}, \mathrm{mp} 156{ }^{\circ} \mathrm{C}$ (lit. $7,20157-159,159-160{ }^{\circ} \mathrm{C}$ ). ${ }^{1} \mathrm{H}$ NMR (400 MHz): $\delta 2.66$ $\left(\mathrm{m}, 1 \mathrm{H}, \mathrm{CH}_{2}\right), 2.88\left(\mathrm{~m}, 1 \mathrm{H}, \mathrm{CH}_{2}\right), 3.37\left(\mathrm{~m}, 1 \mathrm{H}, \mathrm{CH}_{2}\right), 3.79\left(\mathrm{~s}, 3 \mathrm{H}, \mathrm{OCH}_{3}\right), 3.91$ $\left(\mathrm{s}, 3 \mathrm{H}, \mathrm{OCH}_{3}\right), 4.14\left(\mathrm{~m}, 1 \mathrm{H}, \mathrm{CH}_{2}\right), 4.69(\mathrm{~s}, 1 \mathrm{H}, \mathrm{OH}), 6.53(\mathrm{~s}, 1 \mathrm{H}, \mathrm{ArH}), 7.37(\mathrm{~s}$, $1 \mathrm{H}, \mathrm{ArH}), 7.42(\mathrm{t}, J=7.6 \mathrm{~Hz}, 1 \mathrm{H}, \mathrm{ArH}), 7.59(\mathrm{t}, J=7.6 \mathrm{~Hz}, 1 \mathrm{H}, \mathrm{ArH}), 7.63(\mathrm{~d}$ $J=7.6 \mathrm{~Hz}, 1 \mathrm{H}, \mathrm{ArH}), 7.64(\mathrm{~d}, J=7.6 \mathrm{~Hz}, 1 \mathrm{H}, \mathrm{ArH})$.

3-Hydroxy-[2-(2,5-dimethoxyphenyl)ethyl]isoindolin-1-one Colorless needles from $\mathrm{MeOH}(87 \%), \mathrm{mp} 178^{\circ} \mathrm{C} .{ }^{1} \mathrm{H}$ NMR $(400 \mathrm{MHz}): \delta 2.97$ $\left(\mathrm{m}, 2 \mathrm{H}, \mathrm{CH}_{2}\right), 3.67\left(\mathrm{~m}, 2 \mathrm{H}, \mathrm{CH}_{2}\right), 3.66\left(\mathrm{~s}, 3 \mathrm{H}, \mathrm{OCH}_{3}\right), 3.70\left(\mathrm{~s}, 3 \mathrm{H}, \mathrm{OCH}_{3}\right), 5.30$ $(\mathrm{s}, 1 \mathrm{H}, \mathrm{CH}), 6.40(\mathrm{~s}, 1 \mathrm{H}, \mathrm{OH}), 6.70(\mathrm{~m}, 3 \mathrm{H}, \mathrm{ArH}), 7.22(\mathrm{~m}, 2 \mathrm{H}, \mathrm{ArH}), 7.57(\mathrm{~d}$, $J=7.6 \mathrm{~Hz}, 1 \mathrm{H}, \mathrm{ArH}), 7.70(\mathrm{~d}, J=7.6 \mathrm{~Hz}, 1 \mathrm{H}, \mathrm{ArH})$.

1,4-Dimethoxy-5,6,8,12b-tetrahydroisoindolo[1,2-a]isoquinolin-8one (7). Colorless needles from $\mathrm{MeOH}(61 \%) \mathrm{mp} 140-141{ }^{\circ} \mathrm{C} .{ }^{1} \mathrm{H}$ NMR $(400$ $\mathrm{MHz}): \delta 2.57\left(\mathrm{~m}, 1 \mathrm{H}, \mathrm{CH}_{2}\right), 2.98\left(\mathrm{~m}, 2 \mathrm{H}, \mathrm{CH}_{2}\right), 3.73\left(\mathrm{~s}, 3 \mathrm{H}, \mathrm{OCH}_{3}\right), 3.99(\mathrm{~s}$, $\left.3 \mathrm{H}, \mathrm{OCH}_{3}\right), 4.70\left(\mathrm{~m}, 1 \mathrm{H}, \mathrm{CH}_{2}\right), 6.02(\mathrm{~s}, 1 \mathrm{H}, \mathrm{CH}), 6.70(\mathrm{~d}, J=8.8 \mathrm{~Hz}, 1 \mathrm{H}, \mathrm{ArH})$, $6.79(\mathrm{~d}, J=8.8 \mathrm{~Hz}, 1 \mathrm{H}, \mathrm{ArH}), 7.41(\mathrm{t}, J=7.1 \mathrm{~Hz}, 1 \mathrm{H}, \mathrm{ArH}), 7.48(\mathrm{t}, J=6.6 \mathrm{~Hz}$, $1 \mathrm{H}, \mathrm{ArH}), 7.83(\mathrm{~d}, J=7.1 \mathrm{~Hz}, 1 \mathrm{H}, \mathrm{ArH}), 8.08$ (d, $J=7.6 \mathrm{~Hz}, 1 \mathrm{H}, \mathrm{ArH})$.

3-Hydroxy-2-[2-(3,4,5-trimethoxyphenyl)ethyl]isoindolin-1-one (h). Colorless needles from $\mathrm{MeOH}(80 \%), \mathrm{mp} 154{ }^{\circ} \mathrm{C} .{ }^{1} \mathrm{H}$ NMR (400 MHz): $\delta 2.91$ $\left(\mathrm{m}, 2 \mathrm{H}, \mathrm{CH}_{2}\right), 3.72\left(\mathrm{~m}, 2 \mathrm{H}, \mathrm{CH}_{2}\right), 3.79\left(\mathrm{~s}, 9 \mathrm{H}, \mathrm{OCH}_{3}\right), 5.31(\mathrm{~s}, 1 \mathrm{H}, \mathrm{CH}), 6.38$ $(\mathrm{s}, 1 \mathrm{H}, \mathrm{OH}), 6.39(\mathrm{~s}, 2 \mathrm{H}, \mathrm{ArH}), 7.20(\mathrm{t}, J=8.8 \mathrm{~Hz}, 2 \mathrm{H}, \mathrm{ArH}), 7.53$ (d, $J=7.5$ $\mathrm{Hz}, 1 \mathrm{H}, \mathrm{ArH}), 7.66$ (d, $J=7.4,1 \mathrm{H}, \mathrm{ArH})$

1,2,3-Trimethoxy-5,6,8,12b-tetrahydroisoindolo[1,2-a]isoquinolin8-one (8). Colorless needles from $\mathrm{MeOH}(80 \%), \mathrm{mp} 173^{\circ} \mathrm{C}$. ${ }^{1} \mathrm{H}$ NMR $(400$ $\mathrm{MHz}): \delta 2.59\left(\mathrm{~m}, 1 \mathrm{H}, \mathrm{CH}_{2}\right), 2.86\left(\mathrm{~m}, 1 \mathrm{H}, \mathrm{CH}_{2}\right), 3.13\left(\mathrm{~m}, 1 \mathrm{H}, \mathrm{CH}_{2}\right), 3.82(\mathrm{~s}, 3 \mathrm{H}$, $\left.\mathrm{OCH}_{3}\right), 3.90\left(\mathrm{~s}, 3 \mathrm{H}, \mathrm{OCH}_{3}\right), 4.08\left(\mathrm{~s}, 3 \mathrm{H}, \mathrm{OCH}_{3}\right), 4.49\left(\mathrm{~m}, 1 \mathrm{H}, \mathrm{CH}_{2}\right), 5.91(\mathrm{~s}$, $1 \mathrm{H}, \mathrm{CH}), 6.42(\mathrm{~s}, 1 \mathrm{H}, \mathrm{ArH}), 7.42(\mathrm{t}, J=7.3 \mathrm{~Hz}, 1 \mathrm{H}, \mathrm{ArH}), 7.41(\mathrm{t}, J=7.3 \mathrm{~Hz}$, $1 \mathrm{H}, \mathrm{ArH}), 7.83(\mathrm{~d}, J=7.4 \mathrm{~Hz}, 1 \mathrm{H}, \mathrm{ArH}), 8.26(\mathrm{~d}, J=7.6 \mathrm{~Hz}, 1 \mathrm{H}, \mathrm{ArH})$.

3-Hydroxy-2-[2-(3-benzyloxy-4-methoxyphenyl)ethyl]isoindolin-1one (i). Colorless needles from $\mathrm{MeOH}(87 \%)$, mp $97{ }^{\circ} \mathrm{C} .{ }^{1} \mathrm{H}$ NMR $(400 \mathrm{MHz})$ : $\delta 2.78\left(\mathrm{~m}, 2 \mathrm{H}, \mathrm{CH}_{2}\right), 3.66\left(\mathrm{~m}, 2 \mathrm{H}, \mathrm{CH}_{2}\right), 3.83\left(\mathrm{~s}, 3 \mathrm{H}, \mathrm{OCH}_{3}\right), 5.03\left(\mathrm{~s}, 2 \mathrm{H}, \mathrm{CH}_{2}\right)$, $5.28(\mathrm{~s}, 1 \mathrm{H}, \mathrm{CH}), 6.32(\mathrm{~s}, 1 \mathrm{H}, \mathrm{OH}), 6.73(\mathrm{~s}, 4 \mathrm{H}, \mathrm{ArH}), 7.30(\mathrm{~d}, J=6.9 \mathrm{~Hz}, 1 \mathrm{H}$, $\mathrm{ArH}), 7.42(\mathrm{~m}, 4 \mathrm{H}, \mathrm{ArH}), 7.58(\mathrm{~d}, J=7.5 \mathrm{~Hz}, 1 \mathrm{H}, \mathrm{ArH}), 7.70(\mathrm{~d}, J=7.3 \mathrm{~Hz}$ $1 \mathrm{H}, \mathrm{ArH})$.

3-Hydroxy-2-methoxy-5,6,8,12b-tetrahydroisoindolo $[1,2-a]$ isoquinolin-8-one (9). Yellow needles from $\mathrm{MeOH}(42 \%), \mathrm{mp} 186{ }^{\circ} \mathrm{C} .{ }^{1} \mathrm{H}$ NMR (400 MHz): $\delta 2.77\left(\mathrm{~m}, 1 \mathrm{H}, \mathrm{CH}_{2}\right), 2.98\left(\mathrm{~m}, 1 \mathrm{H}, \mathrm{CH}_{2}\right), 3.44\left(\mathrm{~m}, 1 \mathrm{H}, \mathrm{CH}_{2}\right)$, $3.93\left(\mathrm{~s}, 3 \mathrm{H}, \mathrm{OCH}_{3}\right), 4.41\left(\mathrm{~m}, 1 \mathrm{H}, \mathrm{CH}_{2}\right), 5.61(\mathrm{~s}, 1 \mathrm{H}, \mathrm{CH}), 6.75(\mathrm{~s}, 1 \mathrm{H}, \mathrm{ArH})$, $7.08(\mathrm{~s}, 1 \mathrm{H}, \mathrm{ArH}), 7.50(\mathrm{t}, J=7.4 \mathrm{~Hz}, 1 \mathrm{H}, \mathrm{ArH}), 7.62(\mathrm{t}, J=7.3 \mathrm{~Hz}, 1 \mathrm{H}, \mathrm{ArH})$, 7.81 (d, $J=7.4 \mathrm{~Hz}, 1 \mathrm{H}, \mathrm{ArH}), 7.89(\mathrm{~d}, J=7.4 \mathrm{~Hz}, 1 \mathrm{H}, \mathrm{ArH})$.

3-Hydroxy-2-[2-(4-benzyloxy-3-methoxyphenyl)ethyl]isoindolin1-one (j). Colorless needles from $\mathrm{MeOH}(88 \%), \mathrm{mp} 109^{\circ} \mathrm{C} .{ }^{1} \mathrm{H}$ NMR $(400$ $\mathrm{MHz}): \delta 2.77\left(\mathrm{~m}, 2 \mathrm{H}, \mathrm{CH}_{2}\right), 3.65\left(\mathrm{~m}, 2 \mathrm{H}, \mathrm{CH}_{2}\right), 3.83(\mathrm{~s}, 3 \mathrm{H}, \mathrm{OCH}), 5.03(\mathrm{~s}$, $\left.2 \mathrm{H}, \mathrm{CH}_{2}\right), 5.26(\mathrm{~s}, 1 \mathrm{H}, \mathrm{CH}), 6.31(\mathrm{~s}, 1 \mathrm{H}, \mathrm{OH}), 6.72(\mathrm{~m}, 4 \mathrm{H}, \mathrm{ArH}), 7.27(\mathrm{~d}, J=$ $7.1 \mathrm{~Hz}, 1 \mathrm{H}, \mathrm{ArH}), 7.44(\mathrm{~m}, 4 \mathrm{H}, \mathrm{ArH}), 7.58(\mathrm{~d}, J=7.6 \mathrm{~Hz}, 1 \mathrm{H}, \mathrm{ArH}), 7.70(\mathrm{~d}$, $J=7.3 \mathrm{~Hz}, 1 \mathrm{H}, \mathrm{ArH})$.

2-Hydroxy-3-methoxy-5,6,8,12b-tetrahydroisoindolo $[1,2-a]$ isoquinolin-8-one (10). Colorless needles from $\mathrm{MeOH}(51 \%), \mathrm{mp} 189^{\circ} \mathrm{C} .{ }^{1} \mathrm{H}$ NMR (400 MHz): $\delta 2.69\left(\mathrm{~m}, 1 \mathrm{H}, \mathrm{CH}_{2}\right), 2.86\left(\mathrm{~m}, 1 \mathrm{H}, \mathrm{CH}_{2}\right), 3.34\left(\mathrm{~m}, 1 \mathrm{H}, \mathrm{CH}_{2}\right)$, $3.74\left(\mathrm{~s}, 3 \mathrm{H}, \mathrm{OCH}_{3}\right), 4.32\left(\mathrm{~m}, 1 \mathrm{H}, \mathrm{CH}_{2}\right), 5.53(\mathrm{~s}, 1 \mathrm{H}, \mathrm{CH}), 6.58(\mathrm{~s}, 1 \mathrm{H}, \mathrm{ArH})$, $7.12(\mathrm{~s}, 1 \mathrm{H}, \mathrm{ArH}), 7.41(\mathrm{t}, J=7.5 \mathrm{~Hz}, 1 \mathrm{H}, \mathrm{ArH}), 7.54(\mathrm{t}, J=7.5 \mathrm{~Hz}, 1 \mathrm{H}, \mathrm{ArH})$, $7.70(\mathrm{~d}, J=7.5 \mathrm{~Hz}, 1 \mathrm{H}, \mathrm{ArH}), 7.81$ (d, $J=7.6 \mathrm{~Hz}, 1 \mathrm{H}, \mathrm{ArH}), 8.40(\mathrm{~s}, 1 \mathrm{H}$, $\mathrm{OH})$.

3-Hydroxy-2-[2-(3,4-methylenedioxyphenyl)ethyl]isoindolin-1-one (k). Colorless needles from $\mathrm{MeOH}(93 \%), \mathrm{mp} 163{ }^{\circ} \mathrm{C} .{ }^{1} \mathrm{H}$ NMR $(400 \mathrm{MHz})$ : $\delta 2.87\left(\mathrm{~m}, 2 \mathrm{H}, \mathrm{CH}_{2}\right), 3.62\left(\mathrm{~m}, 2 \mathrm{H}, \mathrm{CH}_{2}\right), 5.89\left(\mathrm{~s}, 2 \mathrm{H}, \mathrm{O}-\mathrm{CH}_{2}-\mathrm{O}\right), 5.48(\mathrm{~s}, 1 \mathrm{H}$, $\mathrm{CH}), 6.32(\mathrm{~s}, 1 \mathrm{H}, \mathrm{OH}), 6.60(\mathrm{~m}, 2 \mathrm{H}, \mathrm{ArH}), 6.66(\mathrm{~s}, 1 \mathrm{H}, \mathrm{ArH}), 7.18(\mathrm{t}, J=8.8$ $\mathrm{Hz}, 2 \mathrm{H}, \mathrm{ArH}), 7.56(\mathrm{~d}, J=7.6 \mathrm{~Hz}, 1 \mathrm{H}, \mathrm{ArH}), 7.66(\mathrm{~d}, J=7.3 \mathrm{~Hz}, 1 \mathrm{H}, \mathrm{ArH})$.

$5,6,8,12 \mathrm{~b}$-Tetrahydrodioxolo $[4,5-g]$ isoindolo $[1,2-a]$ isoquinolin-8-one (11). Colorless needles from $\mathrm{MeOH}(54 \%)$, mp $205^{\circ} \mathrm{C}$ dec. (lit. ${ }^{21} 179-180^{\circ} \mathrm{C}$ ). ${ }^{1} \mathrm{H}$ NMR $(400 \mathrm{MHz}): \delta 2.76\left(\mathrm{~m}, 2 \mathrm{H}, \mathrm{CH}_{2}\right), 3.34\left(\mathrm{~m}, 1 \mathrm{H}, \mathrm{CH}_{2}\right), 4.21(\mathrm{~m}, 1 \mathrm{H}$, $\left.\mathrm{CH}_{2}\right), 5.75(\mathrm{~s}, 1 \mathrm{H}, \mathrm{CH}), 5.93\left(\mathrm{~s}, 1 \mathrm{H}, \mathrm{O}-\mathrm{CH}_{2}-\mathrm{O}\right), 6.02\left(\mathrm{~s}, 1 \mathrm{H}, \mathrm{O}-\mathrm{CH}_{2}-\mathrm{O}\right), 6.78(\mathrm{~s}$, $1 \mathrm{H}, \mathrm{ArH}), 7.35(\mathrm{~s}, 1 \mathrm{H}, \mathrm{ArH}), 7.53(\mathrm{t}, J=7.6 \mathrm{~Hz}, 1 \mathrm{H}, \mathrm{ArH}), 7.69(\mathrm{~m}, 2 \mathrm{H}, \mathrm{ArH})$, $8.13(\mathrm{~d}, J=7.6 \mathrm{~Hz}, 1 \mathrm{H}, \mathrm{ArH})$.

2,3-Dihydroxy-5,6,8,12b-tetrahydroisoindolo[1,2-a] isoquinolin-8-one (12). A solution of $6(1.0 \mathrm{~g}, 3.4 \mathrm{mmol})$ in $30 \mathrm{~mL} \mathrm{CH}_{2} \mathrm{Cl}_{2}$ was added dropwise, with efficient stirring, to $\mathrm{BBr}_{3}(0.8 \mathrm{~mL}, 8.4 \mathrm{mmol})$. Stirring was continued at room temperature for $2 \mathrm{~h}$. The reaction mixture was poured into water and extracted with $\mathrm{CH}_{2} \mathrm{Cl}_{2}$. The $\mathrm{CH}_{2} \mathrm{Cl}_{2}$ layer was washed with $\mathrm{H}_{2} \mathrm{O}$ and dried over $\mathrm{Na}_{2} \mathrm{SO}_{4}$, and the solvent was evaporated to dryness to leave a residue which was recrystallized from $\mathrm{MeOH}$ to afford $\mathbf{1 2}$, brownish-red needles $(0.72 \mathrm{~g}$, $80 \%$ ), mp $180^{\circ} \mathrm{C} .{ }^{1} \mathrm{H}-\mathrm{NMR}\left(400 \mathrm{MHz}, \mathrm{CDCl}_{3}\right): \delta 2.73\left(\mathrm{~m}, 1 \mathrm{H}, \mathrm{CH}_{2}\right), 2.86(\mathrm{~m}$, $\left.1 \mathrm{H}, \mathrm{CH}_{2}\right), 3.41\left(\mathrm{~m}, 1 \mathrm{H}, \mathrm{CH}_{2}\right), 4.33\left(\mathrm{~m}, 1 \mathrm{H}, \mathrm{CH}_{2}\right), 5.59(\mathrm{~s}, 1 \mathrm{H}, \mathrm{CH}), 6.63(\mathrm{~s}, 1 \mathrm{H}$, $\mathrm{ArH}), 7.13(\mathrm{~s}, 1 \mathrm{H}, \mathrm{ArH}), 7.49(\mathrm{t}, J=7.4 \mathrm{~Hz}, 1 \mathrm{H}, \mathrm{ArH}), 7.62(\mathrm{t}, J=7.4 \mathrm{~Hz}, 1 \mathrm{H}$, $\mathrm{ArH}), 7.77(\mathrm{~d}, J=7.4 \mathrm{~Hz}, 1 \mathrm{H}, \mathrm{ArH}), 7.90(\mathrm{~d}, J=7.6 \mathrm{~Hz}, 1 \mathrm{H}, \mathrm{ArH}), 8.41$ (as, $1 \mathrm{H}, \mathrm{OH}), 8.50$ (br s, $1 \mathrm{H}, \mathrm{OH})$.

3-Hydroxy-2-[2-(4-dimethylaminophenyl)ethyl]isoindolin-1-one (I). Yellow needles from $\mathrm{MeOH}(76 \%), \mathrm{mp} 136{ }^{\circ} \mathrm{C} .{ }^{1} \mathrm{H}$ NMR (400 MHz): $\delta 2.83$ $\left(\mathrm{m}, 2 \mathrm{H}, \mathrm{CH}_{2}\right), 2.89\left(\mathrm{~s}, 6 \mathrm{H}, \mathrm{NCH}_{3}\right), 3.62\left(\mathrm{~m}, 2 \mathrm{H}, \mathrm{CH}_{2}\right), 5.59(\mathrm{~s}, 1 \mathrm{H}, \mathrm{CH}), 6.42(\mathrm{~s}$, $1 \mathrm{H}, \mathrm{OH}), 6.63(\mathrm{~d}, J=8.6 \mathrm{~Hz}, 2 \mathrm{H}, \mathrm{ArH}), 7.09(\mathrm{~d}, J=8.6 \mathrm{~Hz}, 2 \mathrm{H}, \mathrm{ArH}), 7.19(\mathrm{~m}$, $2 \mathrm{H}, \mathrm{ArH}), 7.56$ (d, $J=7.4 \mathrm{~Hz}, 1 \mathrm{H}, \mathrm{ArH}), 7.69$ (d, $J=7.4 \mathrm{~Hz}, 1 \mathrm{H}, \mathrm{ArH})$.

\section{ACKNOWLEDGMENTS}

This work was supported by CONICYT grant AT-23070040 and ICM grant P05-001-F. V. C.-C. is the recipient of a MeceSup (UMCE-0204) fellowship.

\section{REFERENCES}

1.- A. Morrell, M. Placzek, S. Parmley, B. Grella, S. Antony, Y. Pommier, M. Cushman, J. Med. Chem. 50, 4388, (2007).

2.- IUPAC. Pure Appl. Chem. 71, 2349, (1999).

3.- M. Winn, H. E. Zaugg, J. Org. Chem. 33, 3779, (1968).

4.- $\quad$ G. N. Walker, R. J. Kempton, J. Org. Chem. 36, 1413, (1971).

5.- J.-L. Fabre, D. Farge, C. James, U.S. Patent 4,128,650 (1978)

6.- E. Sobarzo-Sánchez, B. K. Cassels, C. Jullian, L. Castedo, Magn. Reson. Chem. 41, 296, (2003).

7.- M. I. Collado, I. Manteca, N. Sotomayor, M.-J. Villa, E. Lete, J. Org. Chem. 62, 2080, (1997).

8.- J. L. Moniot, D. M. Hindenlang, M. Shamma, J. Org. Chem. 44, 4347, (1979)

9.- H. Heaney, K. F. Shuhaibar, Synlett 1995, 47, (1995).

10.- Collado, M.I.; Sotomayor, N.; Villa, M-J.; Lete, E., Tetrahedron Lett., 37, 6193, (1996).

11.- A. R. Katritzky, S. Mehta, H.-Y. He, J. Org. Chem., 66, 148, (2001).

12.- E. Valencia, A. J. Freyer, M. Shamma, V. Fajardo, Tetrahedron Lett. 25, 599, (1984).

13.- R. Alonso, L. Castedo, D. Domínguez, Tetrahedron Lett. 26, 2925 , (1985).

14.- Y. Koseki, S. Kusano, H. Sakata, T. Nagasaka, Tetrahedron Lett. 40, 2169, (1999).

15.- S. M. Allin, C. J. Northfield, M. I. Page, A. M. Z. Slawin, Tetrahedron Lett. 39, 4905, (1998).

16.- (a) B. Burns, R. Grigg, V. Santhakumar, V. Sridharan, P. Stevenson, T. Worakun, Tetrahedron 48, 7297, (1992),

17.- A. Bombrun, O. Sageot, Tetrahedron Lett. 38, 1057, (1997).

18.- R. Grigg, W. S. MacLachlan, D. T. MacPherson, V. Sridharan, S. Suganthan, M. Thornton-Pett, J. Zhang, Tetrahedron 56, 6585, (2000).

19.- A. Moreau, A. Couture, E. Deniau, P. Grandclaudon, S. Lebrun, Tetrahedron 60, 6169, (2004). 
20.- A. Moreau, A. Couture, E. Deniau, P. Grandclaudon, Eur. J. Org. Chem. 2005, 3437, (2005).

21.- Wakchaure, P.B.; Easwar. S.; Puranik. V.G.; Argade, N.P. Tetrahedron, 64, 1786, (2008)

22.- Zubkov, F.I.; Ershova, J.D.; Orlova, A.A.; Zaytsev, V.P.; Nikitina, E.V.; Peregudov, A.S.; Gurbanov, A.V.; Borisov, R.S.; Khrustalev, V.N.; Maharramov, A.M.; Varlamov, A.V. Tetrahedron, 65, 3789, (2009).
23.- I. Osante, E. Lete, N. Sotomayor, Tetrahedron Lett. 45, 1253, (2004).

24.- T. Bousquet, J-F. Fleury, A. Daïch, P. Netchitaïlo, Tetrahedron 62, 706, (2006).

25.- E. Sobarzo-Sánchez, Síntesis y reactividad en el ámbito de las $7 H$ dibenzo $[d e, h]$ quinolinas. Ph.D. Thesis, Faculty of Sciences, University of Chile (2003). 